\title{
HISTORICAL ANALYSIS OF CIVIL-MILITARY RELATIONS IN NEPAL
}

\author{
Khadga K.C. ${ }^{*}$
}

\begin{abstract}
As like in other developing democracies, it is obvious that there are many CMR problems in Nepal. A lack of national security policies and common national interests, ignorance about security sensitiveness, political instability, parochialism, mistrust, are prominent factors contributing to Nepal's adverse civil-military relations. However, the military though has already begun to tuning with democratic norms and values should further be engaged in serious organizational reform that includes among others; enhancing professionalism, further accountability, transparency and loyalty of army to the civilian authority follow by earliest promulgation of democratic constitution with the clear provision of democratic control over armed forces.
\end{abstract}

\section{BACKGROUND}

Once you have educated, orderly, upstanding and free citizens you will have disciplined and obedient soldier (Tocqueville, 1960: 650-651).

The ferment civil-military relation is one of the key factors of dedemocratization. Unless the military and police forces are under the full control of democratically elected officials, democratic political institutions are unlikely to develop or endure. In contrast to the external threat of foreign intervention, perhaps the most dangerous internal threat to democracy comes from leaders, who have access to the major means of physical coercion; the military and police. "If democratically elected officials are to achieve and maintain effective control over military and police forces, members of the police and military, especially among the officers, must defend to them" (Ibid: 1949). Defense planning and professionalization of armies have always been one of the most sensitive issues in promoting civilian control of the armed forces, ensuring democratic control of defense planning is a challenging task and South Eastern European, Latin American, African and some Asians`experience to date has inevitably been mixed.

The Civil-military relations discourses were articulated on the basis of the assumptions of Huntington and Janowitz's classical works; The Soldier and the State (1957) and The Professional Soldier (1960), which addressed democratic civilian control, military effectiveness and efficiency.

However, the problem is that they focused much on democratic civilian control over the security; which has been more than sufficiently reviewed and criticized over the years and are not found useful under the present circumstances.

A new arguments of civil-military relations, proposed byThomas C. Bruneau and Florina Cristina Matei, which deals with three dimensions: the civilmilitary relations trinity of democratic control, effectiveness, and efficiency (the

Dr. K.C. is an Associate Professor, Masters` in International Relations and Diplomacy, T.U., Kathmandu, Nepal. 


\section{HISTORICAL ANALYSES OF CIVIL-MILITARY ...}

last dimension is not examined by the authors) (Bruneau, 2006: 776-790). These two dimensions are mainly used by democratically elected leaders to exercise control over defense planning process. For example: Huntington's formulation is problematic, first of all because it is "closely linked to the US democratic experience, of questionable relevance elsewhere in the world." Huntington advanced his notions of "objective" and "subjective" control explicitly around the assumption of a clear separation of responsibilities between the civil and military sectors with the military having a clearly defined, autonomous and professionalized area of responsibility, exclusively concerned with the management and application of force. Peter Feaver came with the paradigm that laid out an agency theory of civil military relations, which he argued should replace Huntington's institutional theory. He proposes an ambitious new theory that treats civil-military relations as a principal-agent relationship, with the civilian executive monitoring the actions of military agents, the "armed servants" of the nation state. Taking a rationalist approach, he used a principal-agent framework, to explore how actors in a superior position influence those in a subordinate role.

He used the concepts of "working" and "shirking" to explain the civil military relation is a key aspect of national security policy. The goal of national security policy is to nurture the safety of the nation's social, economic and political institutions against threats arising from other independent states. National security policy may be thought of as existing in three forms and on two levels. "Military security policy is the program of activities designed to minimize or neutralize efforts to weaken or destroy the nation by armed forces operating from outside its institutional and territorial confines" (Huntington, 1985: 1). Civil military relation is the principal institutional component of military security policy. The immediate operating issues of military policy normally involve;

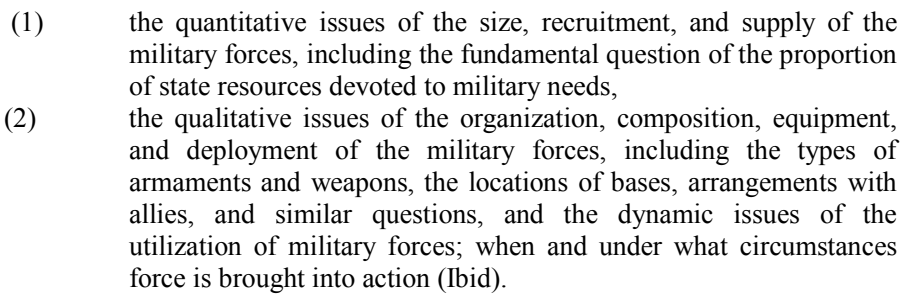

Democracies must pursue a state of civil military relations that aspires to the following normative ideal: a strategically effective military whose leadership provides strategically sound advice to strategically competent civilian authorities. Civil-military relations have become an object of universal concern in the post-modern world in which we live. What militaries do and look like, where they properly fit in the societies of which they are a part, and how they are used and kept in check are enduring concerns that have acquired new life, form, and meaning in an age that is materially different from our modern past. This paper critically argues on the civil-military relations in Nepal in different political set up. It also tries to recommend what should be done a head to build healthy and functioning civil-military relations in Nepal.

\section{PRINCIPLES AND PRACTICES}

Civil-military relations is argued that 'the civilian supremacy in civilmilitary interactions, which is one of the most important attributes of liberal democracy and contributes to decrease military adventurism, compared with their 
civilian counterparts, the military are not likely to advocate the use of force, since the lives of their personnel are at stake" (Janowitz, 1981: 5-15; Dimond, 1999 and Gelpi, 2004). There also is such a tacit compact that binds the three parties to the civilmilitary relationship to one another: the people, the civilian officials who represent the people and oversee the military, and the military itself. What, as part of this social contract, is the military's proper role? Is it to serve itself, in the manner of a selfinterested interest group? Few but those in uniform, convinced of the supernal sanctity of their mission, would subscribe to this narrow view. Or is the military's proper role to serve a particular regime in power or to serve the state, as perhaps all too many of us have come to believe and even accept? Or is the military's role to serve something higher society or even humanity, as pretentious as that might sound? To choose these more elevated objects of military purpose is to raise the bar of public expectations well beyond where it traditionally has been set and to bring into question the sense of identity common to most militaries. This brings us to the central question that must be asked if sound civil-military relations are to be achieved in any democratic society: How does an inherently authoritarian institution (which the military is) that employs violence on behalf of the state, subscribes to an ethos of obedience, cloaks itself in secrecy, and demands exclusivity (all of which the military does) achieve legitimacy?

The first dimension of the civil-military relations trinity to be analyzed is democratic civilian control and oversight. Strong civilian democratic control is the main element for a sound defense planning system, especially for the countries in transition to democracy and good governance. "Oversight focuses on resource and organizational management, professional expertise, and the establishment of a security community within civil society. Oversight as the civilians actually keeps track of what the armed forces or other security forces do; if they are in fact following the direction and guidance they receive" (Thomas, 2006: 910). An executive which has first to learn about transparent planning cycles and gain self-confidence in the implementation; "A legislative power which needs to learn about guidance and oversight mechanisms; a national media and institutions of civil society which need to change their expectations from commenting on the successes of authoritarian leadership to the assumption of the responsibility for public oversight" (Philipp and Eden, 2006: 17).

Military effectiveness, which refers to whether the military can actually fulfill the roles and missions assigned to it by the civilian leadership, and the means by which a democracy exercises civilian control over its armed forces. The question of measuring effectiveness to see how successful the defense and security reforms are in the new democracies from Asia, Africa, Latin America including Southern Europe, or to improve them, is nevertheless an extremely difficult task. Similarly, the defense planning has always been one of the most sensitive issues in promoting civilian oversight of the armed forces. The problem with better understanding this concept and the defense planning methodologies is that there is a significant gap in the professional and academic literature on this matter. It is a fundamental premise of democratic civilmilitary relations that civilian control of the military is clearly possible without democracy, but democracy isn't possible without civilian control of the military. Civilian control is, in fact, the governing concept most familiar to those who concern themselves with civil-military relations, but there are two other related notions that warrant explication here: civilian supremacy and civilian subjugation. Civilian control is the provision of oversight and the issuance of direction to the military by duly elected and 
appointed civilian officials. Oversight implies supervisory vigilance, to be sure, but it also is an essentially responsive activity. Direction gives the concept of control a more proactive managerial connotation in which the military is strictly the executor of decisions issuing properly from civilian superiors.

Feaver comments,

Civilian officials initiated the most aggressive and successfully imperialist militarism in modern times, while military dictators were pacific in response to national security issues. Several studies of US foreign policy suggest the existence of civilian hawks and military doves, especially during the postVietnam War period" (Feaver and Gelpi, 2004).

Further, within civilian regimes in the United States, Latin America, and Eastern Europe, the military do not generally adopt a hawkish standpoint relative to civilian. Other studies of civil-military relations, however, claim that, "while civilian leaders are anticipated to be dovish, military leaders are expected to be hawkish, at least in relation to each other" (Allison, 1985). Barnett identifies "the powerful influence of the German army as a crucial factor in producing World War I. During the era of imperial Japan, to cite what is arguably the archetypal case, the weak leadership often caused international disputes" (Barnett, 1970). In the same vein, Brucher reports that "the military in power are likely to employ violence or severe violence, even if alternative techniques of crisis management are available" (Brucher, 1996: 215-230). The civil-military relations can be studied on the regime type of each state based on three categories; civilian, civilian-military, and military.

The poles of debate on the meaning and importance of civilian control were clearly expressed more than sixty years ago by the two antagonists in the famous Truman-MacArthur controversy during the Korean War. President Truman, writing later in his memoirs, had this to say on the subject:

If there is one basic element in our Constitution, it is civilian control of the military. Policies are to be made by the elected political officials, not by generals or admirals. I have always believed that civilian control of the military is one of the strongest foundations of our system of free government (Truman, 1956: 444-45).

But here is what General MacArthur, the man Truman fired as commander of U.S. and UN forces in Korea, argued in vindication of his outspoken opposition to presidential policies at the time:

\footnotetext{
I find in existence a new and heretofore unknown and dangerous concept that the members of our armed forces owe primary allegiance and loyalty to those who temporarily exercise the authority of the executive branch of government, rather than to the country and its Constitution which they are sworn to defend. No proposition could be more dangerous. None could cast greater doubt upon the integrity of the armed services. For its application would at once convert them from their traditional and constitutional role as the instrument for the defense of the Republic into something partaking of the nature of a praetorian guard, owing sole allegiance to the political master of the hour (Schlesinger, 1992: 318).
}

Significantly, both men invoked the Constitution to defend their positionsTruman to legitimize the very principle of civilian control as a bulwark of freedom, and MacArthur to justify insubordination to civilian political superiors (who, in his eyes, weren't actually superior). For Truman, the Constitution is clear and leaves no room for interpretation about the unequivocal authority of the civilian commander in chief. For MacArthur, there is no higher authority in the affairs of state than the Constitution-the ultimate embodiment of the principle that the rule of law supersedes 
rule by man in a democracy. Whether Truman or MacArthur was more right is the question-and enduringly important, but also extraordinarily elusive, question. Laws and regulations are the most obvious, common, and ostensibly conclusive such mechanisms-especially in that they provide a tangible manifestation of the primacy of the rule of law in a democracy. Although regime type has been the most discussed nonmaterial contributor to date, many other possibilities exist.

The first wave of study, Samuel .P. Huntington, Michael Eliot Howard, Morris Janowitz, and Samuel E. Finer, the prominent scholars of this period, developed major theories from their empirical observations of western democracies. Huntington's main argument was that military professionalism, especially within the officer corps on the model of US military custom in the 19th until mid-20th centuries, is the decisive concept to keep the military out of politics. This functional approach is linked to technical expertise and military secondary virtues, such as discipline, accuracy, military craft and a high degree of responsibility to the public and its citizens. This professionalism makes the officer corps focus its loyalty on the military ideal. "Motivated by this loyalty, such a politically neutral military would ultimately accept the civilian authority as the legitimate superior of the state and carry out its orders without a risk of military intervention" (Huntington, 1957: 84-88, 534). Janowitz did not agree with this logic, concluding "in a more sociological approach that transformation in technology and society, as well as in missions, had led to an even greater political role of the military. For him, this role, however, was far from involvement like a coup d'etat', at least in the US, due to the apolitical ethic of this military profession" (Janowitz, 1960). The second wave of study ranges from 1963 to 1979 during the political changes underwent in Spain and Portugal as well as in Latin America and developments in Asia and Africa, all strongly connected to strong military involvement as the outcomes and the likeliness of coups d'état. The research of this likeliness gained momentum through the developments in Turkey (1960), France (1961), and Greece (1967). The third wave of democratization, beginning in 1989 drew the attention in the field of civil-military relations research to the modernization challenges face by countries of post-communist Europe, then transforming into democracies and reforming their armed forces and security sectors. The advent of major theoretical paradigms, such as neo-realistic, post-modernistic, social constructivist, liberalist, positivistic, and rational choice approaches, changed the respective methodological angles towards civil-military relations.

The fourth-wave work dealt with civil-military relations in post conflict states as well as the initial missions and operations of the European Security and Defense Policy with a view to civil-military cooperation. "Along with that, domestic factors, characteristics, and norms within EU candidate states as well as institutional reform capability itself were examined" (Anthon, 2009:2-11). It is commonplace that civil-military relations can be gauged by the way interactions of policy and operations take place. However, "institutional set-ups, rules, norms, principles, and decision-making procedures, all affecting civil-military relations, are different among EU member states due to their national, cultural, historical, and political distinctiveness" (Stephan, 1983: 2-4).

Armed forces in European context are always understood as an institution which is inherently undemocratic in aspects of their inner structure due to its hierarchical organization and the requirements of operations, to include combat. Yet 
the European Union boasts armies in a democracy and, in fact, a union of democracies. This understanding follows an organizational sociological approach, which allows for the identification of specific organizational characteristics, which can be decoupled from individuals. Such a theoretical approach undergirds such discussion and it's essential for an examination of democratic civil military relations in the domestic politics, society and political culture of the leading EU nations. The civil-military relations in North and Western Europe have proven matured due to the consolidated form of democracies and socio-political acculturation of the political leadership there. However, the young democracies in the Eastern Europe and relatively unstable Southern Europe have been facing challenges to maintain balanced civil-military relations. In relative terms, the latter have passed the most difficult part of their development to democratic civilian control of the armed forces, reaching a level close to the requirements for NATO membership. These countries are a slow and uncertain process, due to the lack of experience and expertise on the part of the both civilians and militaries and their inability to adapt this new concept of defense planning. Nevertheless, the South and Eastern European countries made some progress in building armed forces which are under democratic control and established within a clear legal and institutional framework to ensure civil-military relations.

Similarly, in Asia, Pakistan's politics has been shaped by the dynamics of civilian-military relations and Islamism's relation to the state. This always create bargaining for power in which the military, civilian politicians and Islamist forces have individually and in alliance with one another vied for control of Pakistan's politics. The military stands a better chance of wielding influence on key policy decisions and allocation of resources from the sidelines. This saves the military from hazards of direct assumption of power and gives space to elected civilians. Thus, civil-military relations in established democracies are relatively better than in the new and instable democracies in Asia, Africa and Latin America, including South and Eastern Europe.

\section{CIVIL-MILITARY RELATIONS IN NEPAL}

"The civil-military problems of the new democracies took one of the three forms, depending on the type of authoritarian regime, the power of the military establishment, and the nature of the transition process" (Huntington, 1991: 231-232). The concept of the nation-state in Nepal began in 1768-69, after the conquest of the Kathmandu valley by Prithivi Narayan Shah, the King of Gorkha."It was the final conquest that integrated the country after a series of unification battles" (Bhandari, 2008). Even prior to unification a stable CMR had existed in Nepal. 'Although the military played a crucial role in King Prithwi's most ambitious unification process, he always tried to strike a balance between military autonomy and control. He even sought consent from the general populace to make decisions regarding military matters" (Ibid).

King Prithivi Narayan Shah's maxims demonstrate how cautious he was about civilian military relations at that time. He said, "If the king is wise, he will keep the soldiers and the peasants on his side" (Prithivi Narayan Shah Devko Divya Upadesh, 1953). He also emphasized the professionalism of the soldiers, and said, "Soldiers should be always honed" (Ibid). After Sugauli Treaty 1816, a series of political crises sprang up in Nepal and ultimately empowered Jang Bahadur Rana to usurp absolute power over the country. From 1846 to 1950 was 
a period of oligarchy and agnate regime in Nepalese history. While ruling the country, the Ranas kept the king as the ceremonial head of the state.

Thus, after the emergence of Nepal as a nation-state in the last quarter of the eighteenth century, the primary goal of the Nepali regimes became the maintenance of the status quo, which meant the succession of the delicate balance of power among the various elite families composing the court. The transfer of the capital from Gorkha to Kathmandu in 1769 gave added emphasis to the nationwide scope of the new political system, but did not result in any significant changes in the political process itself. Such political legacy would have significant repercussions impacts on political development and CMR in Nepal.

\section{KING MAHENDRA`S TAKE OVER IN 1960}

Until 1951, Nepal was under the oligarchic Rana rule, and the Nepal Army was loyal to the Rana rulers. Since1950, with the shift of the state's executive power to the king, the Nepal Army eventually had shifted its loyalty to the king (Kumar, 2008: 140). During the transition, the king remained influential over the military due to his crucial position on state power. The king became more powerful when the governmental effectiveness appeared dwarf as the opposition political parties constantly discredited ministers. Rose and Schulz point out "the king strengthened the military in order to check political disorder and counter the armed threats from private police groups" (Rose and Scholz 1980: 43). Following the first general election in February 1959, Nepal's first democratically elected government took office in May, B.P. Koirala as the prime minister, the leader of the Nepali Congress. The Nepali Congress Cabinet had an opportunity to hold the position of the Ministry of Defense, but it seemed like that it was somehow unable to pay much attention to defense affairs or to take necessary steps to maintain civilian control of the military. This also allowed the king to take control of the military even when the Nepali Congress was in power.

Nearly two years after his takeover, King Mahendra proclaimed a new constitution for Nepal, establishing so-called party less directive-democratic Panchayat system on 16 December 1962 . The constitution had a provision dispensing the king privileged authorities to control the military. He was the supreme commander of the military with discretionary power "to raise and maintain armed forces; to grant commissions in such forces; to appoint Commanders in Chief and to determine their powers, duties and remunerations (Art. 64. 1and 64.2)." There was also a constitutional provision that clearly spelled out that "no bill or amendment relating to the armed forcesshall be introduced in either House of Parliament without the recommendations of His Majesty (Art. 64.3)" (Joshi, 1966: 291).

With the support of the military, the king wielded enormous power. This became particularly crucial following the royal coup. The king established the Military Secretariat in the palace to secure total control of the military and at the same time to discourage any possible military alliances or independent power base. This mechanism also enabled him to cut off the military from any political affinity; thus, it focused on professionalism. Bhuwan Lal Joshi and Leo E. Rose mention, "Fully cognizant of the role played by the army in the mid-nineteenth century developments which deprived the ruling dynasty of all but nominal sovereign powers, King Mahendra has taken care to emasculate the military as a potent political force and with considerable success" (Ibid: 390). Since after royal coup, the number of troops 


\section{HISTORICAL ANALYSES OF CIVIL-MILITARY..}

was increased and it was given a modest budget, but it was barred from other political influence and was made loyal to the king and the Panchayat system. Keeping the totally under the direct control of monarch, there was no room for civilian control over armed forces throughout the Panchyat era. Realizing that the military can be a formidable political strength, the king always relied on the military for reining the country and warding off political mobilization against him. Rose and Scholz say that Mahendra "kept active military officers strictly out of politics. Thus the army remained an important but isolated institution" (Rose and Scholz, 1980).

\section{THE POST 1990 CMR}

Since after the restoration of democracy in 1990, the Constitution followed by the movement for the first time took some initiatives towards the civilian control over army through "Provisions regarding the Royal Nepal Army" with stipulation of a National Defense Council (NDC) in Article 118" (The Constitution of the Kingdom of Nepal 2047, (199) However, the military and civilian leaderships functioned as two distinct groups under constitutional monarchy. "The weak and intemperate government could not hold on to the constitutional power to practice. Several governments formed after the 1991 parliamentary elections did not institutionalize the NDC" (Kumar, 2010: 145). The 1991 Constitution ensured a democratic system with a constitutional monarchy but kept the army under ambiguous control. Although leverage in exercising control over the army was given to civilian leaders' through the Ministry of Defense and the National Security Council, it assumed like that the ultimate authority to mobilize and control the army was vested in the king. The rationale of the NDC was eventually accepted only in course of army operation and mobilization against the Maoist Insurgency. The immediate Home Minister Govinda Raj Joshi had tendered his resignation after the Dunai incident happened on 29 September 2000, in which he had a strong disagreement with the army for not providing support to the police against the Maoists' attack. When Prime Minister Girija Prasad Koirala ordered the NA to mobilize against the Maoists who had abducted a group of police personnel in Holeri in July 2001, the army showed reluctance to mobilize. The army did not show insubordination; however, it set many prerequisites for mobilizing the army in counterinsurgency, such as declaration of an emergency, consensus from all political parties, and labeling the Maoists as terrorists.

The most important factor was the mutual mistrust between the military and the Nepali Congress, which remained in the government most of the time. Henceforth, constitutional provision of the NDC became the matter of dispute between the unwilling monarch and the not seemed-like assertive executive prime minister ultimately ending up into the resignation of the Prime Minister, who was then head of the majority party government on 19 July, 2001. Relations between army and political parties' led governments have become inherently conflictridden because the military with its corporate interests also viewed the politicians as intruders into the established political order. There is thus a persistent problem of reconciliation between democratic political forces and the military.

Dhruba Kumar observed, "The alleged defiance of the Royal Nepal Army to the executive order of the prime minister in Dunai (2000) and Holeri (2001) episodes suggests a gross misunderstanding persisting between the elected representative institutions and the non-elected traditional institutions of the government. Although the Article 118 of the 1990 Constitution has asserted the civilian supremacy 
over the armed forces through the organization of a National Defense Council (NDC), the criterion of its smooth functioning was blurred as the king was made the Supreme Commander-in-Chief of the Royal Nepal Army with the final authority to "operate and use" the army on the recommendation of the NDC (Article 118(2) and Article 119)" (Kumar, 2009). Unlike following the spirit of the 1990 constitution, the king used his discretionary authorities, infringing constitutionalism by revoking the power of the democratically elected executive head of the government. Therefore, the constitutional apparatus enshrined to maintain the democratically elected civilian government control over army was made worthless by the traditional monarch. It was partly caused due to the prevailing Military Act 1959 and the COAS Act 1969, which never realized to update by the post democratic governments.

\section{KING GYANENDRA`S DIRECT RULE}

The king Gyanendra's desire to take advantage of the political chaos during the peak hour of Maoist Insurgency greatly worsened the civil-military relations in nascent political history of Nepal. Since after the king had assumed the state power on February 19, 2005, dismissing the elected government and placing the political parties in the background, the situation followed the military to the central stage of politics and defended royal regime. During the direct rule of king Gyanendra, the number of armed forces drastically increased and the military expenditure was also incremented enormously. The following tables show the changing trend of military expenditure and number of army personnel during the royal regime.

BREADKDOWN OF DEFENSE EXPENDITURE

\begin{tabular}{|c|c|c|}
\hline Fiscal Year & Defense Ministry & Home Ministry \\
\hline $1990 / 91$ & $1,696,671,000$ & $1,324,909,000$ \\
\hline $1991 \div 92$ & $1,967,248,000$ & $1,482,917,000$ \\
\hline $1992 \div 93$ & $2,272,325,000$ & $1,796,961,000$ \\
\hline $1993 \div 94$ & $2,125,943,000$ & $1,861,732,000$ \\
\hline $1994 \div 95$ & $2,744,399,000$ & $2,339,702,000$ \\
\hline $1995 \div 96$ & $3,046,004,000$ & $2,617,408,000$ \\
\hline $1996 \div 97$ & $3,321,344,000$ & $2,957,621,000$ \\
\hline $1997 / \div 98$ & $2,888,561,000$ & $3,483,407,000$ \\
\hline $1998 \div 99$ & $4,447,892,000$ & $4,656,673,000$ \\
\hline $1999 \div 2000$ & $5,025,041,000$ & $5,142,715,000$ \\
\hline $2000 \div 001$ & $6,655,968,000$ & $7,613,750,000$ \\
\hline $2001 \div 2002$ & $9,677,568,000$ & $8,047,515,000$ \\
\hline $2002 \div 003$ & $10,731,056,000$ & $8,021,319,000$ \\
\hline $2003 \div 004$ & $11,131,420,000$ & $8,105,559,000$ \\
\hline $2004 \div 005$ & $13,676,072,000$ & $9,108,794,000$ \\
\hline $2005 \div 006$ & $14,837,914,000$ & $9,914,199,000$ \\
\hline $2007 \div 007$ & $15,207,842,000$ & $11,636,151,000$ \\
\hline $2008 \div 009$ & $16,139,983,000$ & $15,541,050,000$ \\
\hline $2009 \div 2010$ & $18,134,684,000$ & $18,113,839,000$ \\
\hline $2010 \div 2011$ & $23,515,018,000$ & $21,834,451,000$ \\
\hline $2011 \div 012$ & $19,100,966,000$ & $21,614,559.00$ \\
\hline $2012-13$ & $22,040,000000$ & \\
\hline & $24,27,84,88,000$ & \\
\hline & $0 f 101$ & \\
\hline
\end{tabular}

Source: Data from the Ministry of Defense and Ministry of Home Affairs: 2012/2013. 
The security expenditure of the government went high as soon the imposition of the state of emergency in 2001. The budgetary amount allocated to the army since 2001 proved that prevailed over civilian authority. The plight of civilmilitary relations during that time was real deteriorated. Similarly, during the 20012006 periods the number of troops got reached more than double. There were just 46000 troops in 2001, however reached 95753 until at the end of 2005. The total numbers of troops at the moment are 92752 and rest 3000 posts are yet to recruit. The king Gynendra's political ambition resulted in the subjugation of the military as his tool to control state power by mobilizing army against other political forces in the country. With the strong favor of monarch, military predominantly exercised real power against the political parties, civil service, media and civil society.

\section{DEMOCRATIC TRANSITION AND ROLE OF THE ARMY}

The 12 points agreements signed between the then agitating seven parliamentary political parties and the CPN Maoist on November, 2005 culminated to joint popular movement II, which lasted until at the end of April, 2006. The joint popular movement reinstated the dissolved parliament, and ended the executive rule of king Gyanendra. The positive role of the Royal Nepal Army toward the smooth democratic transition from April, 2006 onward is real plausible and appreciable. It was suspected that army could launch coup de tat while monarchy was abolished; however, army soon tuned as per the changing political context and showed its commitments toward democratic governments. The symbiotic relationship between the monarchy and royal military was scrapped after the declaration by the reinstated parliament on 18 May, 2006, stripping the king from the title of the Supreme Commander in-chief and resolutions adopted in relation to the armed forces; the royal army has been remodeled as Nepal Army, the prevailing provision regarding the National Defense Council has been annulled. A National Security Council headed by the prime minister shall control, use and mobilize the army, the cabinet shall appoint the Chief of Army Staff, the title of the Supreme Commander in Chief of the Army has been scrapped, and the issue of mobilization of the army shall be inclusive making it a national institution.

\section{INTERIM CONSTITUTION AND THE PROVISION OF CMR}

Following May 18, 2006 parliamentary declaration, the political parties through CPA showed their commitment to democratize the armed forces, arranging and implementing a detailed action plan to make army more inclusive in composition, sensitive to norms and values of democracy and human rights or to reform it into a professional armed force loyal to the civilian government.

As per the spirit of CPA, the Interim Constitution 2007 in its Article 144.1 stated on the provisions of the NA and appointment of the COAS under the Article 144.2, besides, the Council of Ministers shall control, mobilize, democratize and manage the NA with the consent of the political parties (Article 144.3). The democratic structure and inclusive character shall be developed and maintained following the norms and values of human rights (Article 144.4). The Article 145 of the IC has also enshrined "the scope of the National Security Council membership comprising the Prime Minister, Defense Minister, and Home Minister, along with three other members nominated by the Prime Minister as its members" (Interim Constitution of Nepal, 2007: 64). The constitution has revoked the membership of COAS, and arranged a provision for 
invitees for consultation as per the requirement. Despites, the six cabinet members, the Defense Secretary would be the ex-co-officio secretary of the NSC.

However, the authority to 'control use and mobilize' the armed force has transferred to the president with the due recommendation of the Cabinet (Article 114(3), which made NSC's role secondary. Under the provision of the Interim Constitution, the COAS pledges allegiance to the principle of civilian control over armed force, while taking the oath of office. The transitional provision to the Maoist combatants of the IC 2006 stated, 'The Council of Ministers shall form a special committee to supervise,, integrate and rehabilitate the combatants of the Maoist Army, and the functions, duties and powers of the committee shall be determined by the Council of Ministers (Article 146). The management and monitoring of the arms and army have carried out in accordance with the 'Comprehensive Peace Accord' (CPA) concluded on November 21, 2006 and the agreement regarding the 'Monitoring of Arms and Army Management' reached on December 8, 2006 (Article 147). The duration of the Special Committee has terminated in February 10, 2013 after completion of the overall reintegration and rehabilitation of the ex-Maoist Combatants.

The Interim Constitution also incorporated the provision of $45 \%$ reservation to the so-called Dalits/ethnic, indigenous and women population in the army to ensure the inclusive participation of those downtrodden and marginalized communities in the national army, which was indeed significant achievement. The Interim Constitution also empowered some parliamentary committees i.e. State Affairs Committee and Public Account Committee which can oversight whether army is working as per the prevailing constitution, rules and regulation. Also, the PAC has been empowered to oversight army if army lacks financial transparency. Such constitutional provisions also tried to make army more accountable to civilian authorities. Similarly, another initiative to establish a control mechanism on armed forces was taken through The Military Act 2006, which altered the erstwhile Military Act 1959, was enacted by the Legislative Parliament even before the promulgation of the Interim Constitution. The Act is comprised of rules and regulations on appointment and dismissal, award and punishment, establishment of a military court and everything concerned with Nepal Army. Moreover, Even though the Act failed to define the jurisdiction of National Security Council, it established the NSC and somehow opened up new avenues for the establishment military accountability toward civilian authority.

\section{THE CMR DURING THE MAOIST'S LED-GOVERNMENT}

The post conflict (especially during the Maoists'-led government period) civil-military relations in Nepal developed towards confrontation when the Maoists talked openly about launching of an October Revolution, establishing People's Republic in Nepal, and integrating all the Maoist combatants into the NA. The NA acrimonious a relation with the Maoists' government was further embittered when the NA failed to stop its recruitment drive despite protests from the Maoist camp, stating that it was too late to stop. In the meantime, the Ministry of Defense until then was existed in name however its jurisdiction and performance was not clearly mentioned and defined therefore too, the army have been prevailed on the MOD. Long truancy of a cabinet minister, organization inefficiency, lack of policy clarity and directives impeded the decision-making strengthen of the MOD due to which army remained prevailed over the MOD. 


\section{HISTORICAL ANALYSES OF CIVIL-MILITARY ...}

In this context, as soon as the Maoist's guerilla commander Ram Bahadur alias Badal took in charge of the MOD, the ferment relations between the army and Maoist's led government began. The then defense minister Ram Bahadur Thapa, refused to endorse the routine extension of the tenure of eight Brigadier Generals as recommended by the Army Headquarters. Shortly thereafter, the NA's sports team walked out of a national sports event protesting the late entry given to the Maoists' Peoples Liberation Army. Then, made desperate by their unsuccessful attempts to interfere with the army, the Maoists` led government decided to fire the Chief of the Army Staff, General Katawal, and sent a letter to him ordering that he should have explained why he should not be fired for insubordination and violation of civilian supremacy. This new row in the ongoing civil military tension has polarized political parties. Before the Maoists' decision to fire the army chief, most political parties were in favor of asserting more control over the military.

However, the Maoists' unilateral decision to impose major changes in the army to serve their party's vested interest worried the rest of the political parties. This situation left the Maoists alone, without the support of any other political parties. The moment the Maoists unilaterally fired the army chief, the rest of the political parties requested the president to scrap the cabinet decision. "The issue was dramatized by the dispute over the dismissal of the army chief by the cabinet decision but was ultimately resolved by the president of Nepal. In his resignation letter submitted to the president, the Prime Minister questioned the constitutional right of the president to overrule the executive decision terming it as unconstitutional and illegal interference in the civilian supremacy" (The Resignation Letter submitted to the President Ram Baran Yadav, 2009). "The controversy over the controversial prerogative of the executive prime minister and the president has prompted a critical evaluation of the nature and content of "civilian supremacy" (Kumar, 2010: 111). Subsequently; the ruling United Communist Party of Nepal (Maoist) protested the presidential step and rallied every day for what they call the need to establish civilian supremacy in the country. The post-conflict civil-military problem after the COAS restoration controversy has been taken as the most severe in the history of Nepal.

The NA seemed enjoy close relationship with neither to the Interim Government nor the Maoist-led government. It was crystal clear because army seemed quite unhappy with the so-called fusion between the democratic forces and the Maoists. The civil-military relationship became even worst when the Maoists led the government. Since the NA had fought a hostile counterinsurgency war against the Maoists, the Maoist-led government appeared hatred to the NA on the other hand, the NA leadership seemed reluctant to accept the Maoist's prevail over army. This period can be characterized as a struggle between subjective and objective civilian control over army. Despite the latest problematic civil-military relations, it can be firmly believed that the NA had displayed a great deal of loyalty to the civilian authority in the changing political pretext when new political forces established themselves as legitimate authorities and underwent a successful transition. Eventually, after the abolition of the monarchy and establishment of a republic system, the army has accepted new political framework and values and began to work under the leadership of civilian authority i.e. president as per the constitutional arrangements. 
Civil-military relations are complex and CMR until recently has a fairly non-common discourse in the Nepalese context. Nonetheless, one of the important frameworks for stable civilian control of the military is the constitutional legal framework follow by compatible leadership with democratic values. Therefore, since the erstwhile constitution and rules did allow NA to work under the direct and vibrant leadership of monarch there was not existed democratic control over armed forces. However, since after 2006 parliamentary declaration, and the promulgation of Interim Constitution in 2007 and the Military Act reform, the NA has completely obeyed the civilian authority.

\section{CONCLUSIONS}

A quality of democracy of to be one that provides its citizens a high degree of freedom, political equality, popular control on public policies, civilian control over the military and intelligence services, and elaborate network of other agencies of horizontal accountability, complementing the judiciary. Thus, without a democratic constitution, the rule of law, a system of checks and balances and viable, functioning institutions it would be difficult to conceive of democratic control over security sectors. Furthermore, it would be hard to maintain civilian control over security forces in a country with a weak, risk-averse, infirm and intemperate leadership that desists from taking any initiative to adopt legislations and policies and refuses to implement laws that are relevant to the security sector. Various dynamics come into play for the outcomes of particular civil-military relations. To achieve stable CMR and effective civilian control, various combinations of civilian and military stability can be enforced depending upon the power-sharing agreement and other factors. The CMR does not comprise democratic civilian control; further focuses on; effectiveness in achieving roles and missions; and efficiency of the armed forces. Such neo-institutional framework asserts that the essence of CMR is not just the "civilian control of the military," it is rather an effective use of the military as an instrument of national power by civilians to realize national interests. Without effectiveness, mere democratic control may not serve the purpose of stable CMR and national interests. Yet, civilian control is the primary requirement for stable CMR.

Nepal has facades of democratic institutions and control mechanisms enshrined through 1959, 1962, 1990 and 2007 Constitutions; however, erstwhile three institutional set ups were remained either ineffective or nonfunctional whereas the latest constitutional development heightened the positive expectation toward democratic civil-military relationship. Also, these all past records have proven that merely having constitutional provisions does not ensure good CMR and civilian control over armed forces. There have been bewildered CMR in Nepalese history. The tide of the civil-military problem has reached the record high water mark under the post-conflict Maoist-led government. The swift evolution in Nepalese politics after the end of the Maoist insurgency highlights the dynamic nature of CMR. Political upheaval and the removal of the monarch from the helm of Nepalese politics brought the alliance to the center of state power, where it sought to exert subjective civilian control over the military as it had been under the king.

It is obvious that there are many CMR problems in Nepal. Some dimensions are normative, while others are inherently structural. The lack of a 
strategic culture among the political leadership, ignorance about security, political instability, parochialism and individualism, mistrust, and a lack of national security policies and common national interests are prominent factors contributing to Nepal's adverse civil-military relations. The Ministry of Defense's rudimentary functioning and the monarch's direct control of the army for several years are other important factors. However, the recent constitutional/legal development, changing political set up, exposure of NA through peace keeping operations and other international exposure of training and academic courses inter alias have been largely fostering democratic civil military relations in Nepal.

Despite these, the political stability with good governance is sine qua non for stable CMR without which there always remain ample chances of military intervention in domestic politics. The earliest promulgation of democratic constitution with the clear provision of democratic control over armed forces should be arranged. Their needs an indispensable amendment of the Military Act 2063, regarding the recruitment, termination, and tenure of the COAS, which is mentioned in Clause 11(3) on dismissal of the COAS to make it as per the letter and spirit with the Interim Constitution. The Military Act should be clearly defined; categorically, mentioning the roles and functions of army related with the internal security as well. The role of Ministry of Defense should be strengthening to make immediate and effective relationship between the army and the civilian administration. Reforming the military court is also one of the key measures to improve the CMR. The Clause 78(2) of the prevailing Military Act administers the proceedings of the military court, which yet to have maintained transparency demanded as per the prevailing standard of any democratic regimes. The parliamentary committees i.e. State Affairs and Public Account Committees should be further authorized to oversight the armed forces to make them further accountable to the civilian administration.

The NA should give to expose its soldiers to the outside world i.e. peace keeping operations and professional training so that they can further acculturate with democratic norms and values. The state should make policies to make well-equipped the armed forces so that they would not feel that they are deprived from physical facilities during the democratic regime compare to monarchial rules in the past. It needs to formulate policies and develop programs targeted towards civilian education in defense matters, which may enable civilian leaders to get more knowledgeable on military matters and thus make more qualified of making rational informed policy decisions. The newly inducted 1442 ex-Maoist Combatants into Nepal Army need to be imparted democratic norms and values to make an integrated and professional army so that they can comfortably follow the civilian direction. Inclusiveness, considering the standards of the armed forces should be maintained and spearheaded in the days to come too. The military though has already begun to tuning with democratic norms and values should further be engaged in serious organizational reform that includes among others; enhancing accountability, transparency and loyalty of army to the civilian authority.

\section{WORKS CITED}

Allison, Graham T., Albert Carne sale and Joseph, S. Nye, Jr. (1985). Hawks, Doves, and Owls: An Agenda for Avoiding Nuclear War. Norton, New York. 
Anthony, Forster (2009). Civil-Military and Security Sector Reform: West Looking East, International Relations and Security Network. http://www.ssronline.org/document-result.cfm?id=244(accessed July 20.

Avan, Deborah, D. (1996/1997). “Are the Reluctant Warriors Out of Control? Why the US Military is Averse to Responding to Post-Cold War LowLevel Threats." Security Studies. Vol. 6(2).

Barnett, Correlli (1970). Britain and Her Army, 1509-1970. Morrow, New York.

Bhandari, Keshar Bahadur (2008). "Civil-Military Relations in Nepal." Paper presented at a seminar Organized by the Sangam Institute, Aug 27, Kathmandu.

Brucher, Michael (1996). "Crisis Escalation: Model and Findings". International Political Science Review. 17(2).

Bruneau, Thomas C. and Matei, Cristina Florin (2006). "Towards a New Conceptualization of Democratization and Civil-Military Relations". Democratization 13. No.5, December.

Bruneau, Thomas C (2008). "Democracy and Effectiveness: Adopting Intelligence for the Fight Against Terrorism." International Journal of Intelligence and Counter intelligence. Vol. 21.

Campbell, Kenneth J. (1998). "Once Burned, Twice Cautious Explaining the Weinberger-Powel Doctrine". Armed Forces and Society. 24(3).

Dahl, Robert A. (1979). Polyarchy, Participation and Opposition. Yale University Press, New Haven and London.

Desch, Michael C. (2001). Civilian Control of the Military: The Changing Security Environment. The John Hopkins University Press, Baltimore, MD.

Feaver, Peter D. and Gelpi, Christopher (2004). Choosing Your Battles: American Civil-Military Relations and the Use of Force. NJ and Oxford: Princeton University Press, Princeton.

Fluri, Philip and Cole, Edenm (2006). "DCAF"s Activities in Support of Effective and Democratic Transparent Defense Planning." Connections: The Quarterly Journal. No. 6, 1(5).

Foster, Gregory D. (2005). "Civil-Military Relations: The Postmodern Democratic Challenge." World Affairs. Vol. 167, No. 3, (WINTER).

Huntington, Samuel P. (1985). The SOLDIER AND THE STATE; The Theory and Politics of Civil-Military Relations. Harvard, Harvard University Press.

--- (1968). Political Order in Changing Societies. Yale University Press, New Haven.

--- (1991). The Third Wave of Democratization in the Late Twentieth Century. Norman: University of Oklahoma Press.

Kumar Dhruba (2010). "Challenges to Democratic Control of Armed Forces in Nepal" in Rajan Bhattarai and Geja Sharma Wagle eds. Emerging Security Challenges of Nepal. Nepal Institute for Policy Studies, Kathmandu. 
Kumar, Dhruba (2008). "Democratic Control of Security Forces." in Rajan Bhattarai and Rose Cave, eds., Changing Security Dynamics in Nepal. Nepal Institute of Policy Studies and Safer World, Kathmandu.

Janowitz, Morris (1960). The Professional Soldier: A Social and Political Portrait. Glencoe, III; Free Press.

Joshi, Bhuwan Lal and Leo E. Rose (1966). Democratic Innovations in Nepal: A Case Study of Political Acculturation. University of California Press, Berkley.

Peter A. Hall and Rosemary C.R. (1996). Taylor, "Political Science and the Three New Institutionalism." Political Studies. p. 936.

Philipp Fluri and Eden Cole (2006). "DCAF's Activities in Support of Effective and Democratically Transparent Defense Planning." Connections: The Quarterly Journal. Vol. 1, p. 17.

Prithivi Narayan Shah Devko Divya Upadesh (1953). Kathmandu: Information and Communication Division.

Rizvi, Hasan A. (2011). "On Civil-Military Relations", Journal of the International Institute for Strategic affairs. Tuesday, 27 Dec.

Rose, Leo E. and John T. Scholz (1980). Nepal: Profile of a Himalaya Kingdom. West view Press, Boulder, Colorado.

Schlesinger, Jr. (1992). General MacArthur and President Truman: The Struggle for Control of American Foreign Policy. Transaction Publishers, New Brunswick, NJ, p. 318.

Stephan, Krasner (1983). "Structural Causes and Regime Consequences". International Regime. Cornell University Press, Ithaca.

Tilly, Charles (2007). Democracy. Cambridge University Press Cambridge, New York.

Tocqueville, Alexis de (1960). Democracy in America. J.P. Meyer (ed., Harper and Row, New York.

Truman, Harry S. (1956). Years of Trial and Hope. Doubleday Gar den City, NY. 
APPENDICES

State of Castes/Ethnic Inclusion in Nepalese Army (As of April 1, 2009)

\begin{tabular}{|c|c|c|c|c|c|}
\hline $\begin{array}{l}\text { S. } \\
\text { N. }\end{array}$ & Caste/Ethnic Groups & $\begin{array}{c}\text { Populatio } \\
\text { n (2001 } \\
\text { census) }\end{array}$ & $\begin{array}{c}\text { \% of } \\
\text { Total } \\
\text { Popula- } \\
\text { tion }\end{array}$ & $\begin{array}{c}\text { Represen- } \\
\text { tation in } \\
\text { NA }\end{array}$ & $\begin{array}{c}\text { \%o of } \\
\text { Total } \\
\text { Represen } \\
\text {-tation }\end{array}$ \\
\hline 1. & Chhetri & $3,593,496$ & 15.80 & 39,824 & 43.64 \\
\hline 2. & Brhmin & $2,896,477$ & 12.74 & 7,634 & 8.36 \\
\hline 3. & Magar & $1,622,421$ & 7.74 & 6,444 & 7.06 \\
\hline 4. & Tamang & $12,82,304$ & 5.64 & 5,473 & 6.00 \\
\hline 5. & Newar & $1,245,232$ & 5.48 & 6,035 & 6.61 \\
\hline 6. & Tharu/Chaudhari/ Rajbansi & $1,629,691$ & 7.17 & 4,343 & 4.76 \\
\hline 7. & Gurung & 543,571 & 2.39 & 3,145 & 3.45 \\
\hline 8. & Thakuri & 334,120 & 1.47 & 2,967 & 3.25 \\
\hline 9. & Kami & 895,954 & 3.94 & 2,488 & 2.73 \\
\hline 10. & Rai/Sunuwar & 635,151 & 2.79 & 2,687 & 2.94 \\
\hline 11. & Sanyasi & 199,127 & 0.88 & 2,058 & 2.25 \\
\hline 12. & Damai/Dholi/ Gandharba & 390,305 & 1.72 & 1,900 & 2.08 \\
\hline 13. & Sarki & 318,989 & 1.40 & 1,034 & 1.13 \\
\hline 14. & Gharti/Bhujel & 117,568 & 0.52 & 1,257 & 1.38 \\
\hline 15. & Kumal & 99,389 & 0.44 & 763 & 0.84 \\
\hline 16. & Hajam/Thakur & 98,169 & 0.43 & 707 & 0.77 \\
\hline 17. & Limbu & 359,379 & 1.58 & 434 & 0.47 \\
\hline 18. & Majhi & 72,614 & 0.31 & 325 & 0.47 \\
\hline 19. & Teli/Yadav/Rajput & 304,536 & 1.34 & 260 & 0.28 \\
\hline 20. & Darai & 14,859 & 0.07 & 142 & 0.16 \\
\hline 21. & Sherpa/Thakali & $1,80,558$ & 0.74 & 120 & 0.13 \\
\hline 22. & Dusad/Paswan/Dom & 158,525 & 0.70 & 124 & 0.13 \\
\hline 23. & Danuwar & 53,229 & 0.23 & 104 & 0.11 \\
\hline 24. & Muslim & 971,056 & 4.27 & 12 & 0.01 \\
\hline 25. & Mechhe/Tatma & 3,763 & 0.02 & 47 & 0.05 \\
\hline 26. & Jirel & 5,316 & 0.02 & 52 & 0.06 \\
\hline 27. & Thami & 22,999 & 0.10 & 10 & 0.01 \\
\hline 28. & Chepang & 52,237 & 0.23 & 9 & 0.01 \\
\hline 29. & Pahari & 11,505 & 0.05 & 33 & 0.040 \\
\hline 30. & Raji & 2399 & 0.01 & 06 & 0060 \\
\hline 31. & Others & $\ldots$ & & 821 & 0.9 \\
\hline & Total: & & 100 & & 91,258 \\
\hline
\end{tabular}

Source: CBS for column (b) and (c) and AG Department (Record Office) Nepal Army HQ 
140 HISTORICAL ANALYSES OF CIVIL-MILITARY ...

Participation of Females in Nepalese Army

\begin{tabular}{|c|l|l|l|l|l|l|l|l|l|}
\hline $\begin{array}{c}\text { S. } \\
\text { N. }\end{array}$ & $\begin{array}{c}\text { Castes/ } \\
\text { Community }\end{array}$ & $\begin{array}{c}\text { Officer } \\
\text { First } \\
\text { Class }\end{array}$ & $\begin{array}{c}\text { Officer } \\
\text { Second } \\
\text { Class }\end{array}$ & $\begin{array}{c}\text { Officer } \\
\text { Third } \\
\text { Class }\end{array}$ & $\begin{array}{c}\text { Junior } \\
\text { Commi- } \\
\text { ssion } \\
\text { Officer }\end{array}$ & $\begin{array}{c}\text { Non- } \\
\text { Commi- } \\
\text { ssion } \\
\text { Officer }\end{array}$ & NCE & Total & $\%$ \\
\hline 1. & Chhetri & 3 & 17 & 97 & 37 & 375 & 23 & 552 & 51.44 \\
\hline 2. & Newar & 1 & 9 & 25 & 21 & 68 & 7 & 131 & 12.21 \\
\hline 3. & Brahmin & & 7 & 24 & 23 & 70 & 6 & 130 & 12.12 \\
\hline 4. & Magar & & & 4 & & 37 & 4 & 45 & 4.19 \\
\hline 5. & Tamang & & & 5 & & 38 & 1 & 44 & 4.10 \\
\hline 6. & Thakuri & & 3 & 14 & 3 & 16 & & 36 & 3.36 \\
\hline 7. & Gurung & & 4 & 8 & 1 & 20 & 2 & 35 & 3.26 \\
\hline 8. & Rai, Limbu & & 2 & 5 & & 15 & 1 & 23 & 2.14 \\
\hline 9. & Sanyasi & & & 1 & & 18 & 1 & 20 & 1.86 \\
\hline 10. & Damai, Kamai & & & 1 & & 13 & 2 & 16 & 1.49 \\
\hline 11. & Tharu & & 1 & & & 7 & 1 & 9 & 0.84 \\
\hline 12. & Pode, Sarki & & & & 1 & 1 & 6 & 8 & 0.65 \\
\hline 13. & Gharti & & & & & 1 & 6 & 8 & 0.75 \\
\hline 14. & Kumal & & & & & 4 & 1 & 5 & 0.47 \\
\hline 15. & Thakur/Hajam & & & 2 & & 3 & & 5 & 0.47 \\
\hline 16. & Dhobi & & & & & & 2 & 2 & 0.19 \\
\hline 17. & Dusadh, Gaya & & & & & 2 & & 2 & 0.18 \\
\hline 18. & Suli, Pyatha & & & & 1 & & & & 2 \\
\hline 19. & Sherpa & & & 1 & $\mathbf{8 6}$ & $\mathbf{6 9 5}$ & $\mathbf{5 7}$ & $\mathbf{1 0 7 3}$ & $\mathbf{1 0 0}$ \\
\hline
\end{tabular}

Source: Adjutant General Department, Nepalese Army (Record Office)

Note: Female enrollment in Nepalese Army began in 1962, and as of April 1, 2009 there are a total of 1073 female personnel in all ranks, which makes $1.2 \%$ of the total army strength. The Nepalese Army is aiming to maintain a $5 \%$ female work force of the total strength. Among the officers of the Nepalese Army, female officers make up 7.49\%. Junior Commission and Non-Commission Female Officers constitute 8.01\% and $64.77 \%$ respectively of the total female strength. 